\title{
Hepatoprotective and antioxidant effects of Commelina diffusa Burm extracts on gentamicin-induced liver damage in rats
}

\author{
Kamdem Djoko Serges ${ }^{1}$, Poualeu Kamani Sylviane Laure², ${ }^{2}$ chouwet Moise Legentil ${ }^{3}$, Kodjio Norbert ${ }^{4}$, \\ Kamanyi Albert ${ }^{5}$, Wansi Ngnokam SL ${ }^{6 *}$
}

Dept. of Animal Biology University of Dschang, Faculty of Sciences, University of Dschang, Dschang, Cameroon

*Corresponding Author: Wansi Ngnokam SL

Email: poualeusylviane@yahoo.fr

\begin{abstract}
Commelina diffusa is a plant rich in antioxidant compounds, used in traditional medicine to treat many diseases. This study aimed to evaluate the hepatoprotective and antioxidant activities of aqueous and methanolic extracts of Commelina diffusa. Total phenolic and flavonoids content of extracts were determined. Hepatotoxicity was induced in rats by administration of gentamicin ( $80 \mathrm{mg} / \mathrm{kg}$, i.p.) once daily for 10 days. Simultaneously, extracts were given at doses of $100 \mathrm{and} 200 \mathrm{mg} / \mathrm{kg}$, p.o. At the end of treatment, body weight of rats was measured; blood and liver tissues were collected for biochemical and histopathological analysis. The results showed that aqueous and methanolic extracts of $C$. diffusa contain significant amounts of total phenols and flavonoids. These extracts significantly decreased ( $\mathrm{p}<0.05$ to $\mathrm{p}<0.001$ ) liver weight, activity of transaminases and alkaline phosphatase and the levels of malondialdehyde, bilirubin, LDL cholesterol, triglycerides and total cholesterol. In contrast they significantly increased $(\mathrm{p}<0.05$ to $\mathrm{p}<0.01)$ the body weight of rats, the levels of HDL cholesterol, total protein, glutathione and the activity of catalase and superoxide dismutase. Histopathological examination revealed that extracts protected liver tissues against cell infiltration and centrolobular necrosis induced by gentamicin. These results suggest that Commelina diffusa could protect against hepatotoxic effects of gentamicin.
\end{abstract}

Keywords: Commelina diffusa, Gentamicin, Hepatoprotective activity, Antioxidant.

\section{Introduction}

Liver is the largest organ of the body which performs several physiological functions. It plays an essential role in the metabolism of xenobiotics and many others foreign compounds that enter in the body. ${ }^{1}$ Because of this function, liver is often exposed to various diseases resulting in a number of clinical symptoms. ${ }^{2}$ Liver disorders are the most common health hazard found in developed and developing countries due to dietary habits, chronic alcohol consumption, poor hygiene, smoking, toluene, carbon tetrachloride and use of drugs as diclofenac, paracetamol and gentamicin. Druginduced liver injury constitutes a major health problem. It represents more than $50 \%$ of the acute liver failure according to the United States Acute Liver Failure study group. ${ }^{3}$ About $30 \%$ of patients treated with gentamicin are concerned with hepatotoxicity after a long period of treatment. ${ }^{4}$ Liver diseases have become one of the major causes for morbidity and mortality in humans and animals all over the world. Herbal drugs have gained importance and popularity in recent years because of their safety, efficacy and cost effectiveness. ${ }^{5}$ Plant materials are used as hepatoprotective drugs because most of them are inexpensive, because of their better cultural acceptability, their better compatibility with the human body and their minimal side effects. These herbal drugs have shown the ability to maintain the normal functional statues of the liver with or without fewer side effects. ${ }^{6}$ It has been reported that 160 phytoconstituents from several plants have hepatoprotective activities. ${ }^{7}$

Commelina diffusa Burm, sometimes known as the climbing day flower or spreading day flower is a pantropical herbaceous plant in the dayflower family Commelinaceae. ${ }^{8}$ This herb is widely distributed throughout America, South Asian countries and in Africa. In chinese traditional medicine, it is used to reduce swelling and inflammation. In different countries of Asia, Africa and America, it is commonly used in urinary tract infections, to remove cough with sticky phlegm and in diarrhoea, haemorrhoids, enteritis, eye irritation, conjunctivitis and other eye problems like 
ophthalmia. ${ }^{9}$ C. diffusa extracts contain a high proportion of concentrated antioxidants, which are derivatives of polyphenols. ${ }^{8}$ Antioxidant properties, free radical scavenging abilities and anti-inflammatory activities are the basis of other bioactivities and health benefits, such as anti-aging, anticancer, and defensive activity for cardiovascular diseases, diabetes mellitus, obesity, neurodegenerative and hepatic diseases. ${ }^{10}$ Therefore, the present study was conducted to evaluate the hepatoprotective and antioxidant effects of $C$. Diffusa extracts in rats intoxicated with gentamicin.

\section{Materials and Methods}

\section{Drugs and chemicals}

Different chemicals and solvents used in this study were of analytical grade. They were purchased from Geochim Laboratory Ltd, Bafoussam, Cameroon. Gentamicin and Silymarin were procured from the local pharmacy and the District Hospital of Dschang, Cameroon.

\section{Plant material}

The whole plant was collected at Dschang, West region of Cameroon in February 2017. The plant was authenticated at the National Herbarium of Cameroon by comparison to the voucher specimen registered to number SRFC/35189.

\section{Extraction procedure of plant materials}

The plant was dried at room temperature $\left(24^{\circ} \mathrm{C}-25^{\circ} \mathrm{C}\right)$ away from sun light and ground into a fine powder using an electric blender. This powder was used to prepare aqueous and methanolic extracts.

\section{Preparation of aqueous extract}

Aqueous extract of Commelina diffusa (AECD) was obtained by decoction of $500 \mathrm{~g}$ of powder in $5 \mathrm{~L}$ of distilled water for $40 \mathrm{~min}$. The decoction was then filtered with a whatmann $\mathrm{N}^{\circ} 1$ paper (pore size $\mu \mathrm{m}$ ). The filtrate was evaporated in a ventilated oven heated at $40^{\circ} \mathrm{C}$ to obtain $59 \mathrm{~g}$ paste. The yield extraction was $11.8 \%$

\section{Preparation of methanolic extract}

For this extraction, $400 \mathrm{~g}$ of powder of $C$. diffusa were macerated in $3 \mathrm{~L}$ of methanol (95\%) during 24h. After this time, the macerate was filtrated and evaporated with a rotary evaporator under reduce pressure at 40$45^{\circ} \mathrm{C}$ temperature to obtain $13.6 \mathrm{~g}$ paste (the yield of extraction was $3.46 \%$ ). Methanolic extract of Commelina diffusa (MECD) obtained was concentrated and stored in desiccators for further use.

The plant extracts (aqueous and methanolic) were dissolved in distilled water upon administration to obtain various concentrations that were administered to each animal using endoesophagus borer.

\section{Determination of total phenolic content}

Total phenolic content of $C$. diffusa extracts was determined by the method described by Kodjio et al. ${ }^{11}$ using Folin-Ciocalteu reagent as oxidizing agent and gallic acid as standard. The reaction mixture consisted of $20 \mu \mathrm{L}$ of extracts, $1380 \mu \mathrm{L}$ of distilled water, $200 \mu \mathrm{L}$ of $2 \mathrm{~N}$ Folin-Ciocalteu Reagent and $400 \mu \mathrm{L}$ of $20 \%$ sodium carbonate solution. The mixture was incubated at $40^{\circ} \mathrm{C}$ for $20 \mathrm{~min}$. After cooling, the absorbance was measured at $760 \mathrm{~nm}$. The content of the sample was expressed as mg of GAE (gallic acid equivalent)/mg of extract.

\section{Determination of flavonoids content}

Flavonoid content of $C$. Diffusa extracts was determined by Aluminium chloride method described by Bendjaffer. ${ }^{12}$ The aqueous and methanolic extracts $(100 \mu \mathrm{L})$ were mixed with $1.49 \mathrm{~mL}$ of distilled water and $30 \mu \mathrm{L}$ of a $5 \%$ of $\mathrm{NaNO}_{2}$ solution. After $5 \mathrm{~min}, 30$ $\mu \mathrm{L}$ of $10 \%$ of $\mathrm{AlCl}_{3} \mathrm{H}_{2} \mathrm{O}$ solution was added. After $6 \mathrm{~min}, 200 \mu \mathrm{L}$ of $0.1 \mathrm{M}$ sodium hydroxide and $240 \mu \mathrm{L}$ of distilled were added. The solution was mixed and the absorbance was measured at $510 \mathrm{~nm}$. The total flavonoid content of samples was expressed as $\mathrm{mg}$ of $\mathrm{CE}$ (Catechin equivalent)/mg of extract.

\section{Animals}

Forty-two (42) male's Wistar albino rats (12 weeks old) weighing between 200 to $220 \mathrm{~g}$ were obtained from the Animal House of Department of Animal Biology of Faculty of Science, University of Dschang, Cameroon. They were maintained for a week in natural conditions of temperature and luminosity during which they were fed with standard food and had free access to drinking water. All these procedures were performed in 
accordance with standard ethical guideline of the Laboratory of Animal Physiology and Phytopharmacology, Department of Animal Biology, University of Dschang, Cameroon.

\section{Experimental design}

A total of 42 adults albino rats were divided into seven groups of six animals each. Group1 were considered as the normal control group and received distilled water. Group 2 or negative control group or hepatotoxic group received distilled water. Groups 3 and 4 were treated with AECD at doses of 100 and $200 \mathrm{mg} / \mathrm{kg} /$ day respectively. Groups 5 and 6 received MECD at doses of 100 and $200 \mathrm{mg} / \mathrm{kg} /$ day respectively. Group 7 were considered as positive control and received Silymarin (100 $\mathrm{mg} / \mathrm{kg} / \mathrm{day})$. All these treatments were administrated by oral route for 10 days. During these 10 days, all the animals received an intraperitoneal administration of gentamicin (GM) at dose of $80 \mathrm{mg} / \mathrm{kg}$ except the animals of the normal control group which received $\mathrm{NaCl}(0.9 \%)$.

\section{Blood sample collection}

At the end of the experimental period, body weight of rats was measured. After this, rats were anesthetized by an intraperitoneal injection of Diazepam hydrochloride $(5 \mathrm{mg} / \mathrm{kg}) /$ Ketamine hydrochloride $(50 \mathrm{mg} / \mathrm{kg})$. Blood was collected from each animal by catheterism of abdominal artery into non-heparinized test tubes and allowed to stand during 1 hour before centrifuging at $3000 \mathrm{rpm}$ for 15 minutes. Serum was then collected and used for biochemical analysis.

After blood collection, liver was removed and weighed to determine relative liver weight. Then it was excised into two parts: one part was used for histopathological examination and the other part was crushed in $50 \mathrm{mM}$ potassium phosphate buffer ( $\mathrm{pH}$ 7.4) and the homogenate was used for antioxidant studies.

\section{Biochemical Assay}

Estimation of biochemical parameters (alanine aminotransferase (ALT), aspartate aminotansferase (AST), alkaline phosphatise (ALP), total bilirubine
(TB), total proteins (TP), triglycerides (TG), total cholesterol (TC), HDL and LDL cholesterols was assayed using standard kids.

\section{Antioxidant parameters}

Liver homogenates $(5 \% \mathrm{w} / \mathrm{v})$ were prepared in cold $50 \mathrm{mM}$ potassium phosphate buffer $(\mathrm{pH} 7.4)$. The unbroken cells and cell debris were removed by centrifugation at $1000 \mathrm{rpm}$ for $10 \mathrm{~min}$ using a Remi refrigerated centrifuge. Subsequently, the homogenate was subjected to centrifugation (6000 rpm for $15 \mathrm{~min}$ ) and the supernatant was used for the estimation of gluthation (GSH), malondialdehyde (MDA) and the activities of superoxide dismutase (SOD) and catalase (CAT).

\section{Histopathological studies}

The liver tissue was dissected out and fixed in $10 \%$ formalin, dehydrated in gradual ethanol, cleared in xylene, and embedded in paraffin. Sections were prepared and then stained with hematoxylin and eosin dye for photomicroscopic observation including cell necrosis, fatty change, hyaline regeneration and ballooning degeneration.

\section{Statistical analysis}

Results were expressed as the Mean \pm Standard Error Mean (S.E.M.) Data were analyzed by one way Analysis of Variance (ANOVA) using Graph Pad Prism versus 5.0. The means were separated and compared by post hoc-test of Turkey. $\mathrm{p}<0.05$ was considered as statistical significant.

\section{Results}

\section{Total Phenols and flavonoids content}

Both extracts contain a significant amount of phenolic and flavonoid compounds. However, the methanolic extract contains a higher amount of total phenolic content (18.53 mg of $\mathrm{GAE} / \mathrm{mg}$ of extract) and flavonoids (1.99 $\mathrm{mg}$ of $\mathrm{CE} / \mathrm{mg}$ ) than the aqueous extract (Table 1). 
Table 1: Total content of phenolic and flavonoid compounds

\begin{tabular}{|c|c|c|}
\hline Extracts & $\begin{array}{c}\text { Total phenolic content (mg } \\
\text { of GAE / mg of extract) }\end{array}$ & $\begin{array}{c}\text { Total flavonoid content }(\mathbf{m g} \\
\text { CE / mg of extract) }\end{array}$ \\
\hline AECD & 15.30 & 1.90 \\
\hline MECD & 18.53 & 1.99 \\
\hline
\end{tabular}

\section{Effects on body and liver weight of gentamicin-induced hepatotoxic rats}

As presented in Table 2, gentamicin caused a significant decrease $(\mathrm{p}<0.001)$ in body weight and a significant increase $(\mathrm{p}<0.05)$ in liver weight of rats after 10 days of administration. Treatment with different doses of extracts and silymarin $(100 \mathrm{mg} / \mathrm{kg})$ significantly increased $(\mathrm{p}<0.05 ; \mathrm{p}<0.01 ; \mathrm{p}<0.001)$ the body weight of rats and significantly decrease $(\mathrm{p}<0.05 ; \mathrm{p}<0.001)$ the liver weight compared to hepatotoxic group. Methanolic extract produced the best reduction $(\mathrm{p}<0.001)$ in liver weight.

Table 2: Effects of aqueous and methanolic extracts of Commelina diffusa on body and liver weight of gentamicininduced hepatotoxic rats

\begin{tabular}{|l|c|c|}
\hline Group/Treatment (mg/kg) & Relative body weight (\%) & Relative liver weight (g/100gbw) \\
\hline Normal control & $123.00 \pm 2.42$ & $2.67 \pm 0.08$ \\
\hline Negative control (GM group) & $96.39 \pm 0.60^{\mathrm{c}}$ & $3.09 \pm 0.14^{\mathrm{a}}$ \\
\hline AECD + GM & $106.10 \pm 0.79^{\mathrm{c} \beta}$ & $2.42 \pm 0.04^{\gamma}$ \\
\hline AECD 200 + GM & $104.70 \pm 1.36^{\mathrm{c} \alpha}$ & $2.50 \pm 0.05^{\gamma}$ \\
\hline MECD 100 + GM & $108.40 \pm 2.24^{\mathrm{c} \gamma}$ & $2.32 \pm 0.09^{\gamma}$ \\
\hline MECD 200 + GM & $106.20 \pm 1.62^{\mathrm{c}}$ & $2.32 \pm 0.12^{\gamma}$ \\
\hline Silymarin 100 + GM & $112.40 \pm 1.40^{\mathrm{b \gamma}}$ & $2.54 \pm 0.05^{\beta}$ \\
\hline
\end{tabular}

$\mathrm{AECD}=$ Aqueous extract of Commelina diffusa, $\mathrm{MECD}=$ Methanolic extract of Commelina diffusa. $\mathrm{GM}=$ Gentamicin, bw= body weight

Values are represented as Mean \pm S.E.M.

${ }^{\mathrm{a}} \mathrm{p}<0.05,{ }^{\mathrm{c}} \mathrm{p}<0.001$, significantly different compared to the normal control group;

${ }^{\alpha} \mathrm{p}<0.05 ; \beta \mathrm{p}<0.01 ; \gamma_{\mathrm{p}}<0.001$, significantly different compared to the negative control.

\section{Effects on biochemical parameters of gentamicin-induced hepatotoxic rats}

Effects of $C$. diffusa extracts in biochemical parameters on gentamicin-induced hepatotoxicity are resumed in Table 3. It appears that intraperitoneal injection of gentamicin significantly increased $(p<0.01 ; p<0.001)$ the activities of ALT, AST, ALP, the levels of TB, TC and TG in rats. It did not cause any significant effect $(\mathrm{p}>0.05)$ on the level of TP and HDL and LDL cholesterols. $C$. diffusa extracts significantly decreased $(\mathrm{p}<0.05 ; 0.01 ; 0.001)$ the activities of ALT and ALP when compare to negative control group. Extracts also increased significantly ( $p<0.05$ to 0.01 ) the level of TP and HDL-c compared to negative control group. In the other hand, $C$. diffusa extracts reduced significantly the levels of TB $(\mathrm{p}<0.05 ; \mathrm{p}<0.01)$, TG $(\mathrm{p}<0.001)$ and LDL-c $(0.01)$ when compare to negative control group.

Table 3: Effect of aqueous and methanolic extracts of Commelina diffusa on biochemical parameters of gentamicininduced hepatotoxic rats

\begin{tabular}{|c|c|c|c|c|c|c|c|}
\hline Parameters & $\begin{array}{l}\text { Normal } \\
\text { control }\end{array}$ & $\begin{array}{l}\text { Negative } \\
\text { control }\end{array}$ & $\begin{array}{c}\text { AECD } \\
(100 \mathrm{mg} / \mathrm{kg})\end{array}$ & $\begin{array}{c}\text { AECD } \\
(200 \mathrm{mg} / \mathrm{kg})\end{array}$ & $\begin{array}{c}\text { MECD } \\
(100 \mathrm{mg} / \mathrm{kg})\end{array}$ & $\begin{array}{c}\text { MECD } \\
(200 \mathrm{mg} / \mathrm{kg})\end{array}$ & $\begin{array}{c}\text { Silymarin } \\
\text { (100mg/kg) }\end{array}$ \\
\hline ALT (IU/L) & $29.67 \pm 3.90$ & $57.00 \pm 4.38^{\mathrm{c}}$ & $38.00 \pm 3.12^{\alpha}$ & $33.33 \pm 3.36^{B}$ & $38.33 \pm 4.31^{\alpha}$ & $27.00 \pm 3.08^{\gamma}$ & $44.00 \pm 3.18$ \\
\hline AST (IU/L) & $67.73 \pm 9.53$ & $138.16 \pm 6.5^{\mathrm{c}}$ & $125.80 \pm 7.14^{\mathrm{c}}$ & $113.16 \pm 7.4^{\mathrm{c}}$ & $129.16 \pm 7.57^{\mathrm{c}}$ & $121.3 \pm 11.34^{\mathrm{c}}$ & $160.0 \pm 0.17^{\mathrm{c}}$ \\
\hline ALP (IU/L) & $90.50 \pm 2.872$ & $267.00 \pm 22.58^{\mathrm{c}}$ & $109.20 \pm 7.68^{\gamma}$ & $104.80 \pm 6.96^{\gamma}$ & $199.80 \pm 18.66^{\gamma}$ & $98.83 \pm 18.72^{\gamma}$ & $78.5 \pm 11.87^{\gamma}$ \\
\hline $\mathrm{TP}(\mathrm{g} / \mathrm{dl})$ & $7.72 \pm 1.1$ & $2.10 \pm 0.18$ & $21.92 \pm 6.66^{\mathrm{a} \beta}$ & $6.14 \pm 0.79$ & $16.97 \pm 2.60^{\alpha}$ & $12.03 \pm 2.66$ & $10.50 \pm 3.60$ \\
\hline TB (mg/dL) & $0.90 \pm 0.13$ & $1.40 \pm 0.15^{\mathrm{b}}$ & $1.17 \pm 0.05$ & $0.88 \pm 0.06^{\beta}$ & $1.00 \pm 0.06^{\alpha}$ & $1.21 \pm 0.03$ & $1.36 \pm 0.06^{\mathrm{b}}$ \\
\hline $\mathrm{TC}(\mathrm{mg} / \mathrm{dl})$ & $10.50 \pm 0.34$ & $14.00 \pm 1.98^{\mathrm{c}}$ & $3.83 \pm 0.40^{\mathrm{b} \gamma}$ & $3.50 \pm 0.22^{\text {by }}$ & $4.16 \pm 0.70^{\text {by }}$ & $4.50 \pm 0.34^{\text {b } \gamma}$ & $14.50 \pm 1.62$ \\
\hline TG (mg/dl) & $32.00 \pm 3.44$ & $95.67 \pm 9.54^{b}$ & $43.00 \pm 5.87^{\gamma}$ & $16.33 \pm 4.41^{\gamma}$ & $21.16 \pm 3.13^{\gamma}$ & $42.33 \pm 8.67^{\gamma}$ & $43.38 \pm 8.36^{\alpha}$ \\
\hline
\end{tabular}




\begin{tabular}{|l|c|c|c|c|c|c|c|}
\hline $\begin{array}{l}\text { HDL-C } \\
(\mathrm{mg} / \mathrm{dl})\end{array}$ & $1.99 \pm 0.04$ & $1.74 \pm 0.08$ & $2.26 \pm 0.09$ & $2.92 \pm 0.20^{\beta}$ & $2.36 \pm 0.22$ & $2.81 \pm 0.21^{\beta}$ & $2.82 \pm 0.11^{\beta}$ \\
\hline $\begin{array}{l}\text { LDL-C } \\
(\mathrm{mg} / \mathrm{dl})\end{array}$ & $4.26 \pm 0.59$ & $10.43 \pm 1.33$ & $8.00 \pm 1.73$ & $2.00 \pm 0.36^{\beta}$ & $5.33 \pm 2.44$ & $3.66 \pm 1.05^{\alpha}$ & $3.83 \pm 0.87^{\alpha}$ \\
\hline
\end{tabular}

$\mathrm{AECD}=$ Aqueous extract of Commelina diffusa, $\mathrm{MECD}=$ Methanolic extract of Commelina diffusa .

Values are represented as Mean \pm S.E.M.

${ }^{\mathrm{b}} \mathrm{P}<0.01 ;{ }^{\mathrm{c}} \mathrm{P}<0.001$, significantly different compared to the normal control;

${ }^{\alpha} \mathrm{P}<0.05 ;{ }^{\beta} \mathrm{P}<0.01 ;{ }^{\gamma} \mathrm{P}<0.001$, significantly different compared to the negative control.

\section{Effects on antioxidant biomarkers of gentamicin-induced hepatotoxic rats}

As shown in Table 4, gentamicine significantly increased $(\mathrm{p}<0.05)$ the level of MDA and GSH, and significantly decrease $(\mathrm{p}<0.01)$ the activity of SOD and CAT compared to normal control group. However, treatment of rats with AECD $(200 \mathrm{mg} / \mathrm{kg})$, MECD (100 and $200 \mathrm{mg} / \mathrm{kg})$ and silymarin significantly decreased $(\mathrm{p}<0.05 ; \mathrm{p}<0.01 ; \mathrm{p}<0.001)$ the MDA and GSH levels. In addition, MECD and AECD at the dose of 200mg/kg significantly increased ( $p<0.05$; $\mathrm{p}<0.01)$ the activities of CAT and SOD compared to hepatotoxic group. Only the dose of $100 \mathrm{mg} / \mathrm{kg}$ of MECD resulted in a significant increase $(\mathrm{p}<0.001)$ in CAT activity. In contrast, silymarin produced no significant effect on the activity of CAT and SOD.

Table 4: Effects of aqueous and methanolic extracts of Commelina diffusa on antioxidant parameters of gentamicininduced hepatotoxic rats

\begin{tabular}{|l|c|c|c|c|}
\hline Group/Treatment (mg/kg) & $\begin{array}{c}\text { GSH } \\
\text { (nmol/g tissue) }\end{array}$ & $\begin{array}{c}\text { CAT } \\
\text { (mol/mg tissue) }\end{array}$ & $\begin{array}{c}\text { MDA (mol/mg } \\
\text { tissue) }\end{array}$ & $\begin{array}{c}\text { SOD } \\
\text { (U/mg protein) }\end{array}$ \\
\hline Normal control & $0.145 \pm 0.002$ & $0.241 \pm 0.005$ & $0.630 \pm 0.020$ & $2.230 \pm 0.110$ \\
\hline Negative control & $0.125 \pm 0.007^{\mathrm{a}}$ & $0.152 \pm 0.004^{\mathrm{b}}$ & $0.960 \pm 0.070^{\mathrm{a}}$ & $1.900 \pm 0.060^{\mathrm{b}}$ \\
\hline AECD $(100 \mathrm{mg} / \mathrm{kg})$ & $0.142 \pm 0.003$ & $0.180 \pm 0.007$ & $0.780 \pm 0.120$ & $2.020 \pm 0.002$ \\
\hline AECD $(200 \mathrm{mg} / \mathrm{kg})$ & $0.148 \pm 0.000^{\beta}$ & $0.232 \pm 0.020^{\beta}$ & $0.550 \pm 0.060^{\beta}$ & $2.160 \pm 0.020^{\alpha}$ \\
\hline MECD $(100 \mathrm{mg} / \mathrm{kg})$ & $0.147 \pm 0.0003^{\alpha}$ & $0.210 \pm 0.010^{\gamma}$ & $0.680 \pm 0.040^{\alpha}$ & $2.040 \pm 0.020$ \\
\hline MECD $(200 \mathrm{mg} / \mathrm{kg})$ & $0.148 \pm 0.0003^{\alpha}$ & $0.201 \pm 0.020$ & $0.630 \pm 0.020^{\alpha}$ & $2.010 \pm 0.001$ \\
\hline Silymarin $(100 \mathrm{mg} / \mathrm{kg})$ & $0.145 \pm 0.003^{\beta}$ & $0.202 \pm 0.020$ & $0,510 \pm 0.050^{\gamma}$ & $2.010 \pm 0.004$ \\
\hline
\end{tabular}

$\mathrm{AECD}=$ Aqueous extract of Commelina diffusa, MECD=Methanolic extract of Commelina diffusa.GM= Gentamicin

Values are represented as Mean \pm S.E.M.

${ }^{b} \mathrm{P}<0.01 ;{ }^{\mathrm{c}} \mathrm{P}<0.001$, significantly different compared to the normal control group;

${ }^{\alpha} \mathrm{P}<0.05 ;{ }^{\beta} \mathrm{P}<0.01 ;{ }^{\gamma} \mathrm{P}<0.001$, significantly different compared to the negative control.

\section{Effects on hepatic tissue of gentamicin-induced hepatotoxic rats}

Histological sections of liver are presented in Fig. 1. This figure revealed the normal histology structures of liver in normal control group with normal hepatocytes, centrilobular vein and sinusoidal capillary (Fig. 1TM). In negative control group, significant changes were observed in liver structure with diffuse areas of vacuolar degeneration mainly centrolobular, swelling of cells and congestion of hepatic veins andsinusoids. Liver of rats treated with extracts at dose of $100 \mathrm{mg} / \mathrm{kg}$ showed very little changes in hepatocytes; however, groups treated with AECD at dose of $200 \mathrm{mg} / \mathrm{kg}$ showed moderate vacuolar changes with hepatocytes swelling and lysis of cytoplasm. Liver's sections of rats treated with MECD (200 mg/kg bw), showed vascular congestion and leucocytes infiltration while the liver of those treated with $100 \mathrm{mg} / \mathrm{kg}$ of the same extract appeared normal. 

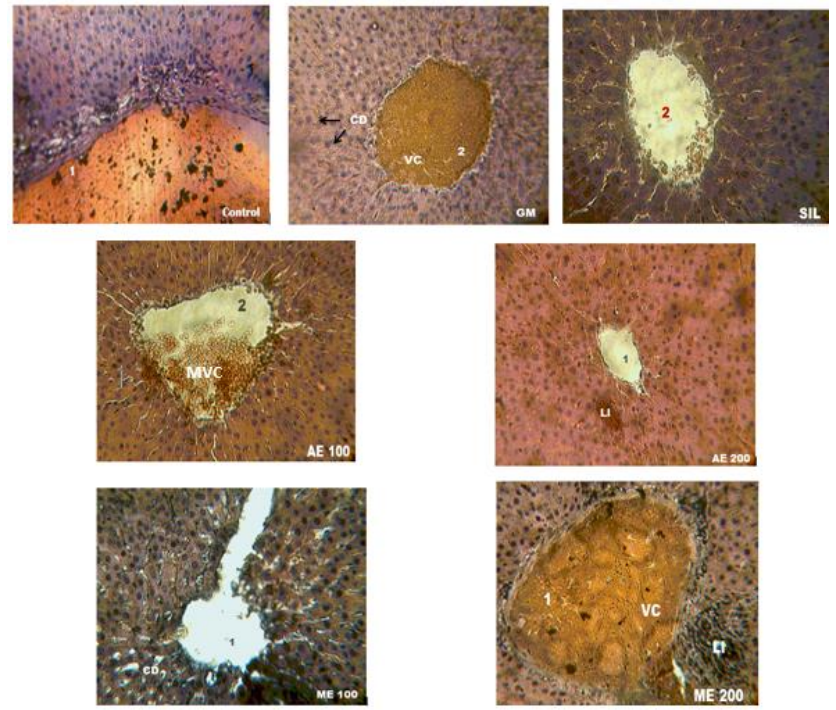

Figure 1: Histological images of livers of rats pretreated with Commelina diffusa extracts and silymarin in gentamicin-induced hepatotoxicity (200x).

\section{Control}

Normal histological appearance cells with normal central and portal vein; GM or gentamicin group:capillary dilation and vascular congestion; SIL: liver section of rats treated with silymarin $(100 \mathrm{mg} / \mathrm{kg})$ showing well brought out central vein (CV) and hepatic cell with well-preserved cytoplasm; AE 100: liver section of rats treated with AECD $(100 \mathrm{mg} / \mathrm{kg})$ showing mild congestion in central vein; AE 200: liver section of rats treated with the AECD $(200 \mathrm{mg} / \mathrm{kg})$ showing regeneration of hepatocytes around central vein with near normal liver architecture; ME 100: liver section of rats treated with the MECD $(100 \mathrm{mg} / \mathrm{kg})$ showing capillaries dilation of sinusoids; ME 200: liver section of rats treated with the MECD $(200 \mathrm{mg} / \mathrm{kg})$ vascular congestion and leucocytes infiltration.

1: portal vein; 2: central vein; CD: capillary dilation; VD: vacuolar degeneration; I: infiltration of leucocytes; VC: vascular congestion; MVC: Mild vascular congestion

\section{Discussion}

The present study was undertaken to evaluate the effects of aqueous and methanolic extracts of C. Diffusa on gentamicin induced hepatotoxicity in rats. Gentamicin is an antibiotic of the aminoglycoside class typically used for moderate to severe gram negative infections. ${ }^{13}$ The aminoglycosides act by binding to the aminoacyl site of $16 \mathrm{~S}$ ribosomal RNA within the $30 \mathrm{~S}$ bacterial ribosomal subunit, leading to misreading of genetic code which in turn alters protein synthesis of bacterial. $^{14}$ Nowadays, the prolonged use of aminoglycosides, particularly gentamicin, becomes a fundamental part of medical practice. However its associated side effects seriously reduce it clinical use. ${ }^{15}$ It has been observed that most patients taking gentamicin encountered liver inefficiency problems. Gentamicin induces free radicals production, which can cause cell death via necrosis. The free radicals also activate the inflammatory response through nuclear factor $\mathrm{kB}(\mathrm{NFkB})$, inducing hepatotoxicity. ${ }^{16}$

In this study, GM treatment significantly reduced the body weight of rats. Similar results were obtained by Gaddam et al. ${ }^{17}$ According to Shamsuyarova, ${ }^{18}$ the recorded body weight loss could be attributed to dehydration and anorexia due to acidosis after administration of gentamicin. $C$. diffusa extracts improved growth performance; this effect could be attributed to the leaves content of the plant. Indeed, it is well known that, $C$. Diffusa leaves contain high crude protein, vitamins (A, B and $\mathrm{C}$ ), phosphorus, iron, calcium. $^{8,19}$

GM administration caused liver injury in rats as indicated by significant increase of ALT and AST activity and increase of liver weight. Increase of ALT and AST activity in gentamicin-induced liver damage is an indicator of hepatocellular leakage and loss of membrane integrity of liver cells. ${ }^{20,21}$ It is well known that gentamicin causes liver damage through oxidative stress that occurs during its metabolism by hepatic microsomes, which in turn leads to lipid peroxidation of cell membranes. ${ }^{22}$ Impairment of hepatic cell or membrane leads to discharge enzyme into circulation. ${ }^{23}$ Hepatic damage observed in this study was confirmed by histological analysis which showed extensive vascular degenerative changes and centrolobular necrosis. Treatment with aqueous and methanolic extracts of $C$. diffusa and silymarin significantly decreased the ALT activity and liver weight meaning that they protected liver cells against gentamicininduced damage. Hepatoprotective effects of $C$. diffusa extracts were clearly established in histological analysis where rats treated particularly with AECD showed very 
little changes of liver architecture when compared to normal control group.

GM significantly increased the serum liver markers function level such as bilirubin and ALP. Rise in serum activity of ALP is due to the increase in its synthesis, in the presence of an increase in biliary pressure due to the effect of a hepatotoxin. ${ }^{24}$ Hyperbilirubinemia is generally associated with hemolysis and blockage of bile duct within the liver. ${ }^{25,26}$ Both extracts significantly reduced these parameters.

Serum proteins level significantly decreased after chronic GM administration. Decrease of total protein levels is also considered as an index of the severity of hepatocellular dysfunction in chronic liver diseases. ${ }^{12}$ In fact, when liver is sick, regulation of protein metabolism is frequently disturbed. One of clinical signs observed after disturbances in proteins metabolism is the low levels of plasma proteins synthesized in the liver. ${ }^{27}$ Increase in TP observed in treated groups suggests that $C$. diffusa could restore the liver integrity and thus its metabolism function.

Chronic GM administration created serious disturbance of lipid profile characterised by a significant increase $(\mathrm{p}<0.01)$ of $\mathrm{TC}, \mathrm{TG}, \mathrm{LDL}-\mathrm{c}$ and decrease of HDL-c in rats. According to Perla et al. ${ }^{28}$ hyperlipidemia induced by gentamicin could reflect the impairment of liver cells to metabolize lipids or lipids peroxidation induction. Additionally, high levels of TG and LDL-C are associated with a high risk of cardiovascular diseases. ${ }^{29}$ The use of $C$. diffusa extracts prevented the gentamicin induced rise in serum lipids and thus could prevent against cardiovascular diseases associated to liver dysfunction.

Most organisms have their antioxidant-based defence mechanisms against free radicals and reactive oxygen species (ROS) damage in which endogenous non-enzymatic and enzymatic antioxidants such as SOD, CAT, and GSH play an important role. SOD, GSH and CAT antioxidant constitute a mutually supportive team of defence against ROS. ${ }^{30}$ The protective role of endogenous antioxidant system in humans is insufficient when free radical species become greater than antioxidant available. ${ }^{31}$ In this case, free radical mainly superoxide radical, hydrogen peroxide, and hydroxyl radical induced oxidative stress with various consequences. In this study, GM significantly reduced the GSH level, the activities of SOD and CAT with an increase of the MDA level. These results suggest that 10 days administration of gentamicin causes lipid peroxidation. According to Ozougwa and Eyo, ${ }^{31}$ the decrease of the activities of antioxidant enzymes may lead to excessive cellular damage by free radical. Lipid peroxidation revealed in gentamicin group was significantly decreased in groups treated with extracts when compared to the negative control group. Simultaneously, significant increase of GSH, SOD and CAT was observed in groups treated with $C$. diffusa extracts and silymarin. SOD is the key defence enzyme that catalyses the conversion of superoxide radical to oxygen and peroxides. Peroxide is then metabolized by CAT into water and oxygen, protecting cells against free radical induced damage by reducing the amount of free radicals in the cells. ${ }^{32}$ These results suggest that aqueous and methanolic extracts of $C$. diffusa possess antioxidant activity. This effect could be attributed to phenolic and flavonoid compounds contained in the plant. It is well known that these compounds are endowed with antioxidant properties. ${ }^{33-}$ 35

Histopathological observations of liver sections showed capillary dilation and vascular congestion in GM group. These abnormalities were totally corrected in groups treated with silymarin and aqueous extract of C. diffusa at dose of $200 \mathrm{mg} / \mathrm{kg}$, evidence of their protective effect against GM induced liver injuries.

\section{Conclusion}

The present study demonstrated the protective activity of $C$. Diffusa extracts against gentamicin induced hepatotoxicity. The results indicated that $C$. diffusa prevented gentamicin-induced liver damage by restoring altered biochemical and histological parameters and its antioxidant defences. These findings provide biochemical and histological data supporting folkloric use of Commelina diffusaBurm .f. in the local treatment of some hepatic disorders.

\section{Conflict of interest}

None.

\section{Conflict of Interest}

None. 


\section{References}

1. Harraz FM, Ghazy NM, Hammoda HM, Nafeaa AA, Abdallah II, . Hepatoprotective and Antioxidant activities of Tribulus terrestris. $J$ Physiol Pharmarcol Adv 2015;5(11):787-94.

2. Srivastava R, Srivastava P. Hepatoprotective and Role of some hepatoprotective plants in present scenario. Global $J$ Dig Dis 2018;4:3.doi: 10.4172/2472-1891.100034

3. Somnath D, Swaminathan SR, Babu AMSS, Aneela S. In-vivo Hepatoprotective Activity of Methanol Extracts of Sphaeranthus amaranthoides and Oldenlandia umbellate. Pharma J 2017;9(1):98-101.

4. Dhodi DK, Bhagat SB, Pathak D, Patel SB. Druginduced nephrotoxicity. Int J Basic Clin Pharmacol 2005; 3:591-7.

5. Haque M, Haque M, Md. Reyad-ul-Ferdous, Hasan M, Tarek H, Md. Noor-A-Alam et al. Screening of Antioxidant and Antimicrobial Properties of the Syzygium jambos L. Am J Biosci 2015;3(2-1):23-6.

6. Hong M, Li S, Tan HY, Wang N, Sai-Wah $\mathrm{T}$, Feng Y et al. Current Status of Herbal Medecines in Chronic Liver Disease Therapy: The Biological Effects, Molecular Targets and Future Prospects. Int J Mol Sci 2015;16(12):28705-45.

7. Handa SS. Evolution of Indian herbal Hepatoprotective Drugs. Fitoterpia 1986;57(5):307-51.

8. Ahem RM. Phytochemical and Biological Investigation of Commelina diffusa. Bachelor Pharm 2017;55.

9. Wansi SL, Djoko SK, Atsamo AD, Ngape RA, Nguelefack-Mbuyo EP, Fofie C et al, . Diuretic activity and toxicological assessment of the aqueous extract from the aerial part of Commelina diffusa in rats. Pharm 2014;5(5):184-90.

10. An-Na L, Li S, Yu-Jie Z, Xiang-Rong X, Yu-Ming C, Hua-Bin L et al. Resources and Biological Activities of Natural Polyphenols. Nutr 2014;6(12):6020-47.

11. Kodjio N, Atsafack SS, Fodouop C, Jules-Roger K. In vitro Antisalmonellal and Antioxidant activities of Extracts and Fractions of Curcuma longa L. Rhizomes (Zingiberaceae). Int J Biochem Sci Res 2016;11(3):1-14.

12. Bendjaffer K, Lamia Z. Etude de l'effet protecteur d'une plante médicinale endémique appartenant au genre Genista vis-à-vis de la toxicité provoquée par la gentamicine. Master'sthesis, Université des Frères Mentouri Constantine 2015;75.

13. Kurt AW, Edwards JD, Jonathan DE. AminoglycosideInduced Nephrotoxicity. J Pharm Practice 2014;27(6):5737.

14. Mingeot-Leclercq MP, Glupczynski Y, Tulkens PM. Aminoglycosides: activity and resistance. Antimicrob Agents Chemother 1999;43(4):727-37.

15. Arafat N, Awadin WF, El-Shafei RA, Farag VME, Saleh RM. Protective role of Moringaoleifera Leaves extract against Gentamicin-induced Nephro and Hepatotoxicity in chickens. Alex J Vet Sci 2018;58(1):173-85.

16. Li J, Zhu X, Liu F, Cai P, Sanders C, Lee WM . Cytokine and auto antibody patterns in acute liver failure. $J$ Immunotoxicol 2010;7:157-64.

17. Gaddam SR, Raparla LP, Reddy GR, Charan DV. Evaluation of Nephroprotective Activity of the Methanolic Extract of Phyllanthus niruri. Int J Pharm Phytopharmacol Res 2012;4(5):276-80.

18. Shamsuyarova A. Overexpression of Catalase prevents gentamicin-induced apoptosis of renal proximal tubular cells in transgenic mice. Master's Thesis, Université de Montréal. 2015;105.

19. Murro JK. "Moringaoleifera leaf meal can replace cotton seed cake in the concentrate mix feed with Rhodes grass (Chlorisgayana) hay for growing sheep". Livest Res Rural Dev 2003;15(11).

20. Sule O, Arhoghro ME. Protective potentials of Bryophyllumpinnatumin in Wistar Rats Against Gentamicin-Induced Biochemical Injury. J Med Biochem Sci Res 2016;2(10):163-7.

21. Ansah C. Terminaliaivorensis A. Chev. Ethanolic Stem Bark Extract Protects Against Gentamicin-Induced Renal and Hepatic Damage in Rats. J App Pharm Sci 2016;(4)6:175-82.

22. Patidar S, Manigauha A, Dubey B. Modulator Efficacy of Dietary Inclusion of Ocimum sanctum Leaves Against Gentamicin-induced Hepatotoxicity in Rats. Indian J Biotech Pharm 2019;7(2):18-30.

23. Okaiyeto K, Nwodo UU, Mabinya LV, Okoh AI. A review on some medicinal plants with hepatoprotective effects. Pharm Rev 2018;12(24):186-99.

24. Monira A, Naima ZM. Evaluation of protective and antioxidant activity of Thyme (Thymus vulgaricus) extract on paracetamol-induced toxicity in rats. Aust J Basic App Sci 2012;6:467-74.

25. Mahmood ND, Mamat SS, Kamisan FH, Yahya F, Kamarolzaman MFF, Nasir $\mathrm{N}$ et al. Amelioration of paracetamol-induced hepatotoxicity in rat by the administration of methanol extract of Muntingiacalabura L. Leaves. Biomed Res Int 2014; doi: 10.1155/2014/695678

26. Minehira K, Gual P. Role of Lipid Droplet Proteins in Development of NAFLD and Hepatic Insulin Resistance. Multidisciplinary Digital Publishing Institute 2017;25p.

27. Charlton MR. Protein metabolism and liver disease. Baillieres Clin Endocrinol Metab 1996;10(4):617-35.

28. Perla FM, Perla FM, Prelati M, Lavorato M, Visicchio D, Anania C et al. The Role of Lipid and Lipoprotein Metabolism in non-Alcoholic Fatty Liver Disease. Children (Basel) 2017;4(6):46.

29. Shebaby WN, Daher CF, El-Sibai M, BodmanSmith K, Mansour A, Karam MC et al. Antioxidant and hepatoprotective activities of the oil fractions from wild carrot (Daucuscarota). Pharm Biol 2015;53(9):1285-94. 
30. Mutiat AO, Ogundare OC, Longe AO. Hepatoprotective effect of Mangifera indica stembark extract on paracetamol-induced oxidative stress in albino rats. Eur Sci $J$ 2015;11(24):299-309.

31. Ozougwa JC, Eyo JE. Hepatoprotective effects of Allium cepa (onion) extracts against paracetamol-induced liver damage in mice. Afr J Biotechnol 2014;13(26):2679-88.

32. Benedet J, Shibamoto. Role of transition metals, Fe (II), Cr (II), $\mathrm{Pb}$ (II) and Cd (II) in lipid peroxidation. Food Chem 2008;107(1):165-8.

33. Kaempe SH, Edi S, Shirley ESK. Potential of phenolic extract of Goroho Banana fruit (Musa spp.) on blood sugar of white rat (Rattus norvegicus). Chem Prog 2013;6(1):6-9.
34. Nahid P. Phenolic Compounds as Potential Antioxidant. Jundishapur J Nat Pharm Prod 2013;8(4):149-5.

35. Zübeyir H, Fükrü B, Elhami G. Antioxidant and Antiradical Properties of Selected Flavonoids and Phenolic Compounds. Bioch Res Int 2017;10p.

How to cite: Serges KD, Laure PKS, Legentil NM, Norbert K, Albert K, Wansi Ngnokam SL. Hepatoprotective and antioxidant effects of Commelina diffusa Burm extracts on gentamicininduced liver damage in rats. J Pharm Biolog Sci 2020;8(1):23-31. 